http://jmscr.igmpublication.org/home/

ISSN (e)-2347-176x ISSN (p) 2455-0450

crossref DOI: https://dx.doi.org/10.18535/jmscr/v7i6.193

\title{
Evaluation of the Piscicidal Effect of Calcium Hypochlorite, a Potential Molluscicde, on Fingerlings of Clarias Gariepinus (Siluriformes: Clariidae)
}

\author{
Author \\ Oniya, M.O. \\ Department of Biology Federal University of Technology, Akure, Nigeria \\ *Corresponding Author \\ Oniya, M. Oladipo \\ Department of Biology, Federal University of Technology, PMB 704, Akure, Ondo state, Nigeria
}

\begin{abstract}
The control of snail intermediate hosts of Schistosoma, the blood fluke, is part of the multi-pronged approach in the control of schistosomiasis. Various molluscicide candidates (synthetic and vegetable) have been documented in literature and these apart from being effective, are also expected to be eco-friendly and not harmful to other non-target organisms in the water bodies where the snails are found. The toxic effect of calcium hypochlorite, a potential molluscicide, on the fresh water fish, Clarias gariepinus was experimentally investigated in the laboratory. Various concentrations of the test chemical viz 6, 8, 10, 15 and $20 \mathrm{mgl}^{-1}$ in well water were set up in different tanks into which five (5) fingerlings each of Clarias gariepinus were introduced. For each concentration there were three replicates and control. After the 48 hour assay, the mean $L C_{50}$ was $12.88 \mathrm{mg} / \mathrm{l}$ and $L C_{95}$ was $17.66 \mathrm{mg} / \mathrm{l}$. Results showed that the test chemical demonstrated Piscicidal effect at concentrations higher than necessary for the control of water snails as reported elsewhere. The significance of the result as it relates to community water treatment and mollusciciding in schistosomiasis control is discussed.
\end{abstract}

Keywords: Calcium hypochlorite, Molluscicide, Toxicity, Clarias gariepinus, Schistosomiasis, Control.

\section{Introduction}

The life cycle of the schistosome trematode parasite is intertwined with aquatic intermediate snail hosts. Thus, mollusciciding has been one of the earliest control programmes (Sturrock, 2001). The major limitation to its broad acceptability lies in the effect of the chemical introduced to other aquatic life apart from the targeted organism(s). Various synthetic and vegetable molluscicide candidates have been reported. These include; Bayluscide (Madsen et. al., 1986), Tetrapleura tetraptera (Adewunmi, 1990), Jatropha gossypyfolia (Adewunmi and Adesogan, 1986) and Calcium hydrchlorite (Oniya et al., 2006). The use of calcium hypochlorite has been shown in the laboratory to achieve $100 \%$ snail kill at $8.32 \mathrm{mg} / \mathrm{l}$ within 12 hours (Oniya et al., 2006). The advantage calcium hypochlorite may have over other candidates lies in its use in communal water treatment for domestic consumption.

However, there is the problem of toxicity in developing and adopting molluscicides. Many 
were originally considered because they were known to kill snails. Since they also kill fish and other animals, and are applied in endemic areas to water which is often the only supply for humans and their domestic animals, preliminary and expansion tests are necessary to confirm their safety before approving their widespread use, especially today when there is a far greater awareness of both toxicological and environmental risks (Sturrock, 1995).

Fishes are major test organisms because of their economic importance, quite apart from being a significant fauna in aquatic habitats. Their biology is well known and they are usually sensitive. Not minding the difficulty associated with collection, transportation to the laboratory and acclimatization, it is always recommended that at least, one species of fish be included in every series of bioassay involving the aquatic biota (Reish and Oshida, 1986). Previous studies have shown that some botanicals are toxic or lethal to various forms of life in water especially fishes. Such studies include potential of Tetrapleura tetraptera and Xylopia aethiopica for schistosomiasis control (Adewumi, 1990; Oniya et al.,2013), acute toxicity of cassava leaf extracts on the African catfish Clarias anguillaris (Aguigwo, 1998), and growth of $C$. anguillaris in sub-lethal concentrations of Kigelia africana (Onusiriuka and Ufodike, 1998).

Therefore, the objective of this study was to investigate the toxicity of calcium hypochlorite, a potential molluscicide on a typical non-target aquatic organism, Clarias gariepinus.

\section{Materials and Methods}

\section{Collection of Test Organism (Clarias gariepinus)}

Two hundred fingerlings of $C$. gariepinus with mean length and mean weight of $2.95 \pm 0.46 \mathrm{~cm}$ and $7.3 \pm 0.62 \mathrm{~g}$ respectively were sourced from the Ondo State Government Fish Farm, located at Alagbaka, Akure, Ondo State. The fishes were brought to the laboratory where 50 fishes were distributed into 4 glass tanks containing 40 litres of water to acclimatize them to the laboratory conditions for one week. The fishes were fed with fish feed procured from the Government fish farm twice daily (i.e. in the morning and evening). Every two days, the water in the tanks were changed and the tanks rinsed. Feeding was discontinued 24 hours prior to the start of the bioassay (Reish and Oshida, 1986). During the period of acclimatization, only two fishes were recorded dead; the first one died on the second day, while the second one died the third day after they were brought to the laboratory.

\section{Preparation of Test Solutions}

The fishes were exposed to different concentrations of calcium hypochlorite solutions of $6,8,10,15$ and $20 \mathrm{mgl}^{-1}$. Three replicates were set up for each concentration. The test solutions were prepared using Olin dry chlorine $(65 \%$ available chlorine calcium hypochlorite). The prepared solutions were left to stand for 6 hours to permit dissolution and homogeneity prior to use. 5 litres of each solution was poured into separate glass tanks measuring $60 \mathrm{~cm} \times 30 \mathrm{~cm} \times 30 \mathrm{~cm}$ to which five (5) fishes were introduced. A control tank containing untreated well water was set-up for all the experiments carried out. The bioassay duration for treatment concentrations and control was 48 hours and mortality assessments were conducted at intervals of 2, 4, 6, 12, 18, 24, 30, 36, 42, 48 hours. At each period, dead fishes observed were taken out of the tanks after confirmation. Immobility and non-response to a needle probe was taken as evidence of death. The experiment was carried out within $24.3-27.4^{\circ} \mathrm{C}$ laboratory temperature.

\section{Data Analysis}

Means and standard errors of means of triplicate measurements of mortality rates were calculated over a period of 48 hours at $6,8,10,10,15$ and $20 \mathrm{mgl}^{-1}$. Concentrations of calcium hypochlorite were determined using Statistical Package for Social Scientists (version 10). Means were separated using Duncan's Multiple Range Test. 
Means of results obtained were subjected to correlation and regression analysis and used for probit computations. Probit analysis or probit regression models was used to analyze data with binary response variables.

\section{Results}

The juvenile fishes subjected to the toxicant displayed abnormal behaviour. The fish were observed swimming weakly, maintaining a vertical swimming position, which was more pronounced in the higher concentrations of 15 and $20 \mathrm{mgl}^{-1}$. No such erratic swimming behaviour was observed in the control and $6 \mathrm{mgl}^{-1}$ concentrated solutions. There was, however, gasping movement of the mouth, initial increased opercula movement and sluggish movement of fins by fishes in 10,15 and $20 \mathrm{mgl}^{-1}$ calcium hypochlorite solutions at $18 \mathrm{~h}$

Immobility and non-response to a needle probe was taken as evidence of death. However, symptoms like restlessness, lying on one side and spasmodic movement of the mouth, fins and tail preceded the eventual death. The death of the fishes followed a similar characteristic pattern. At first, swimming was noticed to have stopped in fishes under stress on account of the chemical. Though still alive, they practically maintained a vertical position in the water, with the head up but when nudged, they moved slightly. On the other hand, dead fishes were discovered floating on the surface of water, with pale skin.

C. gariepinus response to the control and $6 \mathrm{mgl}^{-1}$ treatment was not significant (Table 1). The result showed that mortality of the fingerlings of $C$. gariepinus increased with increasing concentration of calcium hypochlorite and time (Table 2). It was observed that $100 \%$ of the fingerlings died within 36 hours in the tanks with 15 and $20 \mathrm{mgl}^{-1}$. Only $20 \%$ of test organisms in tanks with concentration of $8 \mathrm{mgl}^{-1}$ of calcium hypochlorite died at the end of the 48hours.

During statistical analysis, quadratic and linear bases of the probit analysis graphs were used to calculate the $\mathrm{LC}_{50}$ and $\mathrm{LC}_{95}$. Table 3 shows $\mathrm{LC}_{50}$ and $\mathrm{LC}_{95}$ values at the different times of observation. Figure 1 shows the probit analysis graph for mortality at the end of the 48hours.

Table 1 Multiple Range of Mortality Rate at Different Times for Different Concentrations

\begin{tabular}{|c|c|c|c|c|c|c|c|c|c|c|}
\hline & 2hours & 4hours & 6hours & 12hours & 18hours & 24hours & 30hours & 36hours & 42hours & 48hours \\
\hline Control & $0.00^{\mathrm{a}} \pm 0.00$ & $0.00^{\mathrm{a}} \pm 0.00$ & $0.00^{\mathrm{a}} \pm 0.00$ & $0.00^{\mathrm{a}} \pm 0.00$ & $0.00^{\mathrm{a}} \pm 0.00$ & $0.00^{\mathrm{a}} \pm 0.00$ & $0.00^{\mathrm{a}} \pm 0.00$ & $0.00^{\mathrm{a}} \pm 0.00$ & $0.00^{\mathrm{a}} \pm 0.00$ & $0.00^{\mathrm{a}} \pm 0.00$ \\
\hline $6 \mathrm{mg} / \mathrm{L}$ & $0.00^{\mathrm{a}} \pm 0.00$ & $0.00^{\mathrm{a}} \pm 0.00$ & $0.00^{\mathrm{a}} \pm 0.00$ & $0.00^{\mathrm{a}} \pm 0.00$ & $0.00^{\mathrm{a}} \pm 0.00$ & $0.00^{\mathrm{a}} \pm 0.00$ & $0.00^{\mathrm{a}} \pm 0.00$ & $0.00^{\mathrm{a}} \pm 0.00$ & $0.00^{\mathrm{a}} \pm 0.00$ & $0.00^{\mathrm{a}} \pm 0.00$ \\
\hline $8 \mathrm{mg} / \mathrm{L}$ & $0.00^{\mathrm{a}} \pm 0.00$ & $0.00^{\mathrm{a}} \pm 0.00$ & $0.00^{\mathrm{a}} \pm 0.00$ & $6.67^{\mathrm{a}} \pm 6.67$ & $6.67^{\mathrm{a}} \pm 6.67$ & $6.67^{\mathrm{a}} \pm 6.67$ & $6.67^{\mathrm{a}} \pm 6.67$ & $13.33^{\mathrm{b}} \pm 6.67$ & $13.33^{\mathrm{b}} \pm 6.67$ & $20.00^{\mathrm{b}} \pm 0.00$ \\
\hline $10 \mathrm{mg} / \mathrm{L}$ & $13.33^{\mathrm{a}} \pm 6.67$ & $26.67^{\mathrm{b}} \pm 6.67$ & $33.33^{\mathrm{b}} \pm 6.67$ & $33.33^{\mathrm{b}} \pm 6.67$ & $33.33^{\mathrm{b}} \pm 6.67$ & $33.33^{\mathrm{b}} \pm 6.67$ & $33.33^{\mathrm{b}} \pm 6.67$ & $33.33^{\mathrm{c}} \pm 6.67$ & $33.33^{\mathrm{c}} \pm 6.67$ & $33.33^{\mathrm{c}} \pm 6.67$ \\
\hline $15 \mathrm{mg} / \mathrm{L}$ & $40.00^{\mathrm{b}} \pm 11.55$ & $46.67^{\mathrm{c}} \pm 6.67$ & $53.33^{\mathrm{c}} \pm 6.67$ & $53.33^{\mathrm{c}} \pm 6.67$ & $66.67^{\mathrm{c}} \pm 6.67$ & $80.00^{\mathrm{c}} \pm 6.67$ & $100.00^{\mathrm{d}} \pm 11.55$ & $100.00^{\mathrm{d}} \pm 0.00$ & $100.00^{\mathrm{d}} \pm 0.00$ & $100.00^{\mathrm{d}} \pm 0.00$ \\
\hline $20 \mathrm{mg} / \mathrm{L}$ & $73.33^{\mathrm{c}} \pm 6.67$ & $86.33^{\mathrm{d}} \pm 6.67$ & $93.33^{\mathrm{d}} \pm 6.67$ & $100.00^{\mathrm{d}} \pm 0.00$ & $100.00^{\mathrm{d}} \pm 0.00$ & $100.00^{\mathrm{d}} \pm 0.00$ & $100.00^{\mathrm{d}} \pm 0.00$ & $100.00^{\mathrm{d}} \pm 0.00$ & $100.00^{\mathrm{d}} \pm 0.00$ & $100.00^{\mathrm{d}} \pm 0.00$ \\
\hline
\end{tabular}


Table 2 Mortality rate of $C$. gariepinus in Calcium hypochlorite solutions

\begin{tabular}{|c|c|c|c|c|c|c|c|c|c|c|}
\hline \multirow{3}{*}{ Conc. (mg/l) } & \multicolumn{10}{|c|}{ Mortalities at different times (h) } \\
\hline & \multicolumn{10}{|c|}{ REPLICATE 1} \\
\hline & $2 \mathrm{~h}$ & $4 \mathrm{~h}$ & $6 h$ & $12 \mathrm{~h}$ & $18 h$ & $24 h$ & 30h & $36 h$ & $42 \mathrm{~h}$ & $48 h$ \\
\hline Control (0.00) & 0 & 0 & 0 & 0 & 0 & 0 & 0 & 0 & 0 & 0 \\
\hline 6.00 & 0 & 0 & 0 & 0 & 0 & 0 & 0 & 0 & 0 & 0 \\
\hline 8.00 & 0 & 0 & 0 & 0 & 0 & 0 & 0 & 0 & 0 & 1 \\
\hline 10.00 & 1 & 2 & 2 & 2 & 2 & 2 & 2 & 2 & 2 & 2 \\
\hline 15.00 & 2 & 2 & 2 & 2 & 4 & 4 & 5 & 5 & 5 & 5 \\
\hline 20.00 & 4 & 5 & 5 & 5 & 5 & 5 & 5 & 5 & 5 & 5 \\
\hline \multicolumn{11}{|l|}{ REPLICATE 2} \\
\hline Control (0.00) & 0 & 0 & 0 & 0 & 0 & 0 & 0 & 0 & 0 & 0 \\
\hline 6.00 & 0 & 0 & 0 & 0 & 0 & 0 & 0 & 0 & 0 & 0 \\
\hline 8.00 & 0 & 0 & 0 & 0 & 0 & 0 & 0 & 1 & 1 & 1 \\
\hline 10.00 & 0 & 1 & 1 & 1 & 1 & 1 & 1 & 1 & 1 & 1 \\
\hline 15.00 & 1 & 2 & 3 & 3 & 3 & 3 & 5 & 5 & 5 & 5 \\
\hline 20.00 & 4 & 4 & 5 & 5 & 5 & 5 & 5 & 5 & 5 & 5 \\
\hline \multicolumn{11}{|l|}{ REPLICATE 3} \\
\hline Control (0.00) & 0 & 0 & 0 & 0 & 0 & 0 & 0 & 0 & 0 & 0 \\
\hline 6.00 & 0 & 0 & 0 & 0 & 0 & 0 & 0 & 0 & 0 & 0 \\
\hline 8.00 & 0 & 0 & 0 & 1 & 1 & 1 & 1 & 1 & 1 & 1 \\
\hline 10.00 & 1 & 1 & 2 & 2 & 2 & 2 & 2 & 2 & 2 & 2 \\
\hline 15.00 & 3 & 3 & 3 & 3 & 3 & 5 & 5 & 5 & 5 & 5 \\
\hline 20.00 & 3 & 4 & 4 & 5 & 5 & 5 & 5 & 5 & 5 & 5 \\
\hline
\end{tabular}

Table 3: Lethal Concentrations (LC) of Calcium Hypochlorite at Different Times (h).

\begin{tabular}{|c|c|c|c|c|c|}
\hline \multirow[t]{2}{*}{ Time (hrs) } & \multirow[t]{2}{*}{ Model } & \multirow[t]{2}{*}{ Equation } & \multirow[t]{2}{*}{ R Sq } & \multicolumn{2}{|c|}{$\mathbf{L C}$} \\
\hline & & & & 95 & 50 \\
\hline \multirow[t]{2}{*}{$2 \mathrm{~h}$} & Quad & $y=-0.0036 x^{2}+0.497 x+2.3169$ & 0.90 & 17.04 & 18.17 \\
\hline & Lin & $y=0.2308 x+4.3458$ & 0.84 & 26.27 & 15.89 \\
\hline \multirow[t]{2}{*}{$4 \mathrm{~h}$} & Quad & $y=-0.0008 x^{2}+0.2482 x+4.6022$ & 0.86 & 20.96 & 15.01 \\
\hline & Lin & $\mathrm{y}=0.1837 x+4.9348$ & 0.84 & 22.39 & 14.12 \\
\hline \multirow[t]{2}{*}{$6 \mathrm{~h}$} & Quad & $y=-0.0003 x^{2}+0.1985 x+4.5994$ & 0.85 & 21.15 & 13.77 \\
\hline & Lin & $y=0.1693 x+4.7554$ & 0.85 & 20.84 & 13.22 \\
\hline \multirow[t]{2}{*}{$12 \mathrm{~h}$} & Quad & $\mathrm{y}=-0.0009 x^{2}+0.2465 x+3.8821$ & 0.88 & 19.18 & 13.96 \\
\hline & Lin & $y=0.1654 x+4.5024$ & 0.87 & 20.22 & 12.77 \\
\hline \multirow[t]{2}{*}{$18 \mathrm{~h}$} & Quad & $y=-0.0004 x^{2}+0.2 x+4.0609$ & 0.89 & 19.45 & 13.06 \\
\hline & Lin & $\mathrm{y}=0.1597 x+4.3328$ & 0.88 & 19.50 & 12.32 \\
\hline \multirow[t]{2}{*}{$24 \mathrm{~h}$} & Quad & $y=-0.0002 x^{2}+0.1719 x+4.2019$ & 0.87 & 18.73 & 12.30 \\
\hline & Lin & $y=0.15 x+4.3333$ & 0.87 & 18.58 & 11.83 \\
\hline \multirow[t]{2}{*}{$30 \mathrm{~h}$} & Quad & $\mathrm{y}=-0.001 x^{2}+0.2368 x+3.9424$ & 0.84 & 17.41 & 13.28 \\
\hline & Lin & $y=0.1321 x+4.5487$ & 0.82 & 17.10 & 11.15 \\
\hline \multirow[t]{2}{*}{$36 \mathrm{~h}$} & Quad & $y=-0.0012 x^{2}+0.2606 x+3.3586$ & 0.86 & 17.29 & 13.39 \\
\hline & Lin & $y=0.1358 x+4.2485$ & 0.84 & 17.15 & 11.04 \\
\hline \multirow[t]{2}{*}{$42 \mathrm{~h}$} & Quad & $y=-0.0012 x^{2}+0.2606 x+3.3586$ & 0.86 & 17.29 & 13.39 \\
\hline & Lin & $y=0.1358 x+4.2485$ & 0.84 & 17.15 & 11.04 \\
\hline \multirow[t]{2}{*}{$48 \mathrm{~h}$} & Quad & $\mathrm{y}=-0.0011 x^{2}+0.2515 x+3.055$ & 0.87 & 17.66 & 12.88 \\
\hline & Lin & $\mathrm{y}=0.1389 x+3.9685$ & 0.85 & 17.16 & 10.91 \\
\hline
\end{tabular}

(Quad= Quadratic Model, Lin= Linear Model, $y=$ Lethal Concentration at any time, $\mathrm{x}=$ time, $\mathrm{h}$ ) 


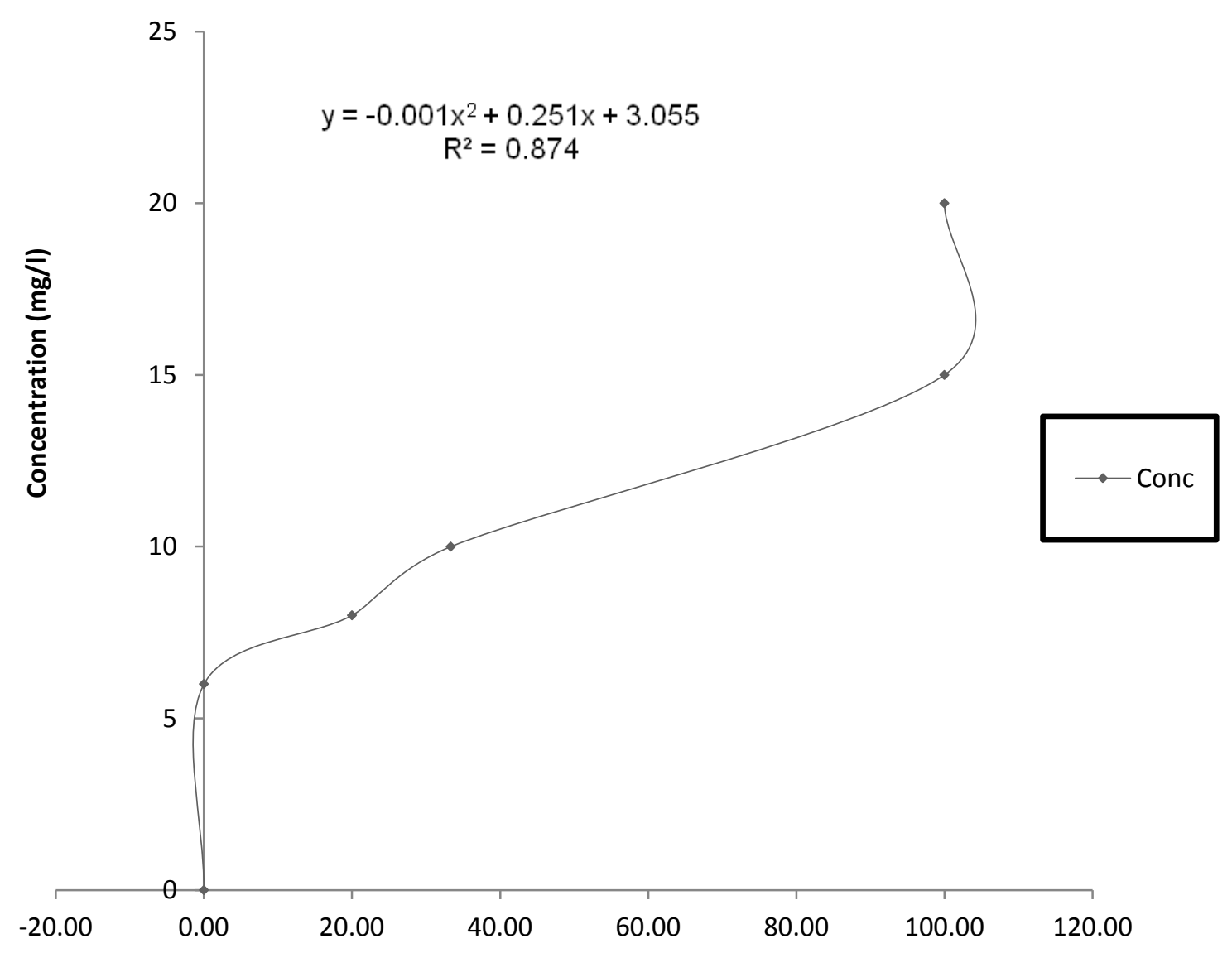

Percentage Mortality

Figure 1: Lethal concentration and mortality rate at $48 \mathrm{~h}$

\section{Discussion and Conclusion}

Schistosomiasis control is a major challenge particularly in tropical Africa, where the major weapon is chemotherapy. This alone cannot solve the problem for a barrage of reasons premised on customs, traditions, poverty and socio - cultural practices (Ukoli, 1987, 1992). However, the use of molluscicides has been included as one of the WHO programmes to stop the transmission of the disease as it kills the snail host. Calcium hypochlorite (Chlorine) has been experimentally shown as a potential molluscicide which is potent at low concentration $\left(\mathrm{LC}_{50} 8.32 \mathrm{mg} / \mathrm{l}\right.$ at $12 \mathrm{~h}$ ), (Oniya et. al., 2006). This median lethal concentration $\left(\mathrm{LC}_{50}\right)$ is the level where some but not all of the organisms succumb (Herzberg, 1988). The present results have also shown calcium hypochlorite to have piscicidal effect on fingerlings of $C$. Gariepinus with an $\mathrm{LC}_{50}$ of $12.88 \mathrm{mg} / \mathrm{l}$ at $48 \mathrm{~h}$. Although there are ethical questions about chemical control since the water serves different purposes for the community, the results of this study showed that the chlorine concentration of $\mathrm{LC}_{50} 8.32 \mathrm{mg} / \mathrm{l}$ required to achieve molluscicidal effect on Bulinus globosus may have low or no mortality effect on $C$. gariepinus, therefore a promising candidate. Apart from this, the chemical is commonly used in the treatment of communal pipe-borne drinking water, pools and ponds to render such safe for drinking. The dual advantage makes the chemical desirable over others as long as field trials show similar positive results. 
The results are suggestive and encouraging for a field trial particularly in climes where the sole weapon in battle is chemotherapy. A multi pronged attack will be more beneficial in the global goal towards eradication of the scourge. Field challenges also subsist; in particular delivery still remains a major task to overcome in the application of molluscicides.

\section{References}

1. Adewumi, C. O. Adesogan, E. K. (1986): Toxicology of some Nigerian plants used in schistosomiasis control. I. The effect of molluscicide on molluscan hearts. Fitoterapia 42.5: 353-358.

2. Adewumi, C.O. (1990). Plant Molluscicides, Potential of Tetrapleura tetraptera for Schistosomiasis Control in Nigeria. Science of the Total Environment 102: 21-33.

3. Aguigwo J.N. (1998). Studies on Acute Toxicity of Cassava Leaf Extracts on the African Catfish, Clarias anguillaris. J. Aquatic Science 13: 31.

4. Editorial Acta Tropica (2000): Posttransmission Schistosomiasis: A New Agenda. Acta Tropica 77 (1):3-7.

5. Herzberg, A. M. (1988): Toxicity and Accumulation of Permethrin in the Tilapia. Oreochromis aureaus. The Isreali Journal of Agric 40 (1):35-39.

6. Madsen, H., Rohde R., Maiga, A.S. (1986): Trials on focal molluscicide application in large irrigation canals and lakes in Mali. Trop. Med. Parasit. 37: 22 24.

7. Oniya, M. O. Awoyemi, S. O. and Dada E. O. (2006): Laboratory evaluation of the molluscicidal activity of calcium hypochlorite on Bulinus globosus. J. Res. Sci. Mgt. 4 (1): 22 - 25.

8. Oniya M.O., Adigun D.O. and Afolabi O.J (2013): Evaluation of the Molluscicidal Activity of Oil Extracts of Tetrapleura tetraptera and Xylopia aethiopica on Bulinus globosus (Mollusca: Planorbidae). Nigerian Journal of Parasitology 34(1):21-24

9. Onusiriuka, B.C. and Ufodike, E.B.C. (1994). Growth of African Catfish, Clarias gariepinus subjected to sub-lethal concentrations of water extracts of Akee Apple, Blighia sapida and Sausage Plant, Kigelia africana. J. Aquatic Sciences 13:59-62

10. Reish DJ, Oshida PS (1986): Manual of methods in aquatic environment research. Part 10, Short- term static bioassays. FAO fish Tech. Paper: 62, 247.

11. Sturrock, R. F. (1995). Current Concepts of Snail Control Memorial Instituto Oswaldo Cruz, 90(2): 241-248.

12. Sturrock, R. F. (2001): Schistosomiasis epidemiology and control: How did we get here and where should we go? Mem. Inst. Oswaldo Cruz. 96 (Suppl.): 17 - 27.

13. Ukoli, F.M.A. 1987. Attitudinal and behavioural aspects of epidemiology and control of parasitic diseases in Tropical Africa. Discourses of the Nigeria Academy of Science. 8.192: 23-43

14. Ukoli F. M. A.1992. Prevention and control of parasitic diseases in Tropical Africa: The main issues. University press PLC Ibadan: 22-32

15. World Health Organization (2004): Schistosomiasis. Division of Control of Tropical Diseases: 5pp. 